\title{
SIMULASI INDEKS PENGGUNAAN AIR (IPA) GUNA PENGHEMATAN AIR IRIGASI DI D.I. SONOSARI DAN D.I. PAKIS KABUPATEN MALANG
}

\author{
Rini Wahyu Sayekti ${ }^{1}$, Endang Purwati $^{2}$, M Janu Ismoyo ${ }^{3}$ \\ ${ }^{1}$ Dosen Jurusan Teknik Pengairan Fakultas Teknik Universitas Brawijaya \\ Teknik Pengairan Fakultas Teknik Universitas Brawijaya-Malang, Jawa Timur, Indonesia \\ Jalan MT.Haryono 167 Malang 65145 Indonesia \\ Email :_rini_ws@ub.ac.id
}

\begin{abstract}
ABSTRAK : Daerah Irigasi Sonosari memiliki 12 petak tersier dengan luas total baku sawah total 801 ha serta saluran sekunder dengan panjang $12 \mathrm{~km}$. Sedangkan Daerah Irigasi Pakis memiliki total luas baku sawah sebesar 726 ha. Dengan total luas baku sawah yang cukup besar serta tidak sesuainya antara kebutuhan air irigasi dengan pemberian air irigasi menyebabkan sering terjadi kekurangan pada musim kemarau. Berdasarkan permasalahan diatas, perlu adanya evaluasi sistem pemberian air irigasi di daerah tersebut dan salah satu caranya adalah dengan metode indeks penggunaan air (IPA) guna mendapatkan nilai debit yang efisien serta nilai FPR yang sesuai dengan jenis tanah.

Dari hasil simulasi IPA didapatkan bahwa dengan mencoba-coba nilai IPA = 0,7 (kategori sedang) memiliki hasil terbesar yaitu 194,389 lt/dtk (Musim Hujan), 213,956 lt/dtk (Musim Kemarau I) dan 116,606 lt/dtk (Musim Kemarau II) pada intake. Untuk penghematan pemberian air irigasi dengan mencoba-coba nilai FPR didapatkan bahwa FPR = 0,12 memiliki hasil terbesar yaitu 363,009 lt/dtk (Musim Hujan), 500,620 lt/dtk (Musim Kemarau I) dan 275,346 lt/dtk (Musim Kemarau II) pada intake. Sementara di D.I. Pakis untuk penghematan pemberian air irigasi yang paling besar, yaitu pada efisiensi 55\% di musim kemarau I sebesar 540,45 lt/dt dengan nilai IPA = 0,55 yang termasuk kategori sedang. Sementara untuk penghematan pemberian air irigasi dengan nilai IPA dan efisiensi yang sama pada musim hujan didapatkan debit sebesar 486,45 lt/dt dan musim kemarau II sebesar $412,20 \mathrm{lt} / \mathrm{dt}$.
\end{abstract}

Kata Kunci: Indeks Penggunaan Air, Kebutuhan Air, Penghematan Air

ABSTRACT : Sonosari Irrigation Region had 12 tertiary patches of rice field at 801 ha total width supported by secondary channel at $12 \mathrm{~km}$ length. Meanwhile Pakis irrigation area have a total of 726 ha. However, the width of the total area of rice fields as well as mismatches between system of water management with demand for water irrigation brought the consequences of water scarcity in the dry season. When water was needed, it overwhelmed the capacity of irrigation region. Water could not afford the remote patch of the rice field. By taking account the problem above, irrigation water system at Sonosari Irrigation Region must be re-evaluated. One way to do this re-evaluation was through water usage index (IPA) can be use for water saving and FPR score also indicated the compatibility of water usage with soil type.

Result of IPA simulation indicated that the obtained IPA score was 0.7 (moderate category) with the biggest water production of 194.389 liters/second (Rain Season), 213.956 liters/second (Dry Season I) and 116.606 liters/second (Dry Season II) on intake. The simulation of irrigation water retrenchment by experimenting FPR scores had given some results. At FPR score of 0.12, there were the biggest water production rates derived at 363.009 liters/second (Rain Season), 500.620 liters/second (Dry Season I) and 275.346 liters/second (Dry Season II) on intake. Meanwhile in Pakis irrigation area found that for the provision of irrigation water savings are greatest, at the efficiency of $55 \%$ in the dry season I at $540.45 \mathrm{~L}$ sec to the value of the IPA $=0.55$ in the medium category. As for the provision of irrigation water savings to the value of IPA and the same efficiency in the wet season discharge obtained at $486.45 \mathrm{~L} / \mathrm{sec}$ and dry season II amounted to $412.20 \mathrm{~L} / \mathrm{sec}$.

Keywords: Water Usage Index, Water Demand, Water Retrenchment 
Pemanfaatan air irigasi di Kabupaten Malang dirasa masih kurang efisien, hal ini dapat dilihat ketika terjadi kekurangan air pada musim kemarau. Pengaturan dan pendistribusian air irigasi tidak dilakukan secara akurat dan efisien akan menyebabkan terjadinya pemberian air yang cenderung berlebihan sehingga mengakibatkan pemborosan penggunaan air.

Daerah Irigasi Sonosari memiliki 12 petak tersier dengan luas total baku sawah total 801 ha serta saluran sekunder dengan panjang 12 km. Sedangkan Daerah Irigasi Pakis memiliki total luas baku sawah sebesar 726 ha. Dengan luas baku sawah total yang cukup besar dan panjang saluran yang cukup panjang menyebabkan sering terjadi kekurangan pada musim kemarau serta pemberian air yang berlebihan sehingga menyebabkan jumlah air yang tersedia tidak dapat menjangkau atau memenuhi petak sawah yang terjauh.

Berdasarkan permasalahan diatas, perlu adanya evaluasi sistem pemberian air irigasi di daerah tersebut dan salah satu caranya adalah dengan metode indeks penggunaan air (IPA). Dengan mensimulasi indeks penggunaan air (IPA) maka akan didapatkan nilai IPA yang efisien serta nilai FPR yang sesuai dengan jenis tanah (teoritis) sehingga dapat digunakan sebagai dasar dalam pemberian air irigasi di Daerah Irigasi Sonosari guna penghematan air irigasi.

Tujuan dari studi ini adalah untuk menentukan indeks penggunaan air (IPA) pada setiap petak tersier serta faktor $\mathrm{K}$ yang efisien sebagai dasar dalam pemberian air irigasi serta sebagai informasi dan evaluasi pemberian air irigasi pada Daerah Irigasi Sonosari kepada instansi yang terkait.

\section{METODOLOGI}

Ditinjau secara administratif, Daerah Irigasi Sonosari terletak di Kecamatan Pakisaji dan Kepanjen, Kabupaten Malang. Daerah Irigasi Sonosari termasuk daerah irigasi kabupatan sehingga pengelolaan pusat ada pada Dinas Pengairan Kabupaten Malang. Tetapi untuk pengelolaan di lapangan diserahkan kepada UPTD Sumber Daya Air dan Irigasi Kepanjen (UPTD Kepanjen). Daerah Irigasi Pakis memiliki luas lahan untuk diairi sebesar 726 Ha. Secara geografis, Daerah Irigasi Pakis terletak pada posisi $112^{\circ} 43^{\prime} 02^{\prime \prime}$ BT dan 7 $57^{\prime} 06^{\prime \prime}$ LU.

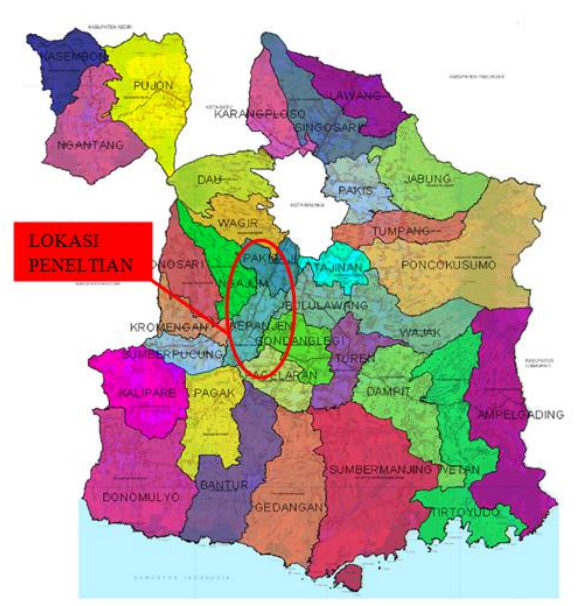

Gambar 1. Peta Lokasi Studi D.I. Sonosari

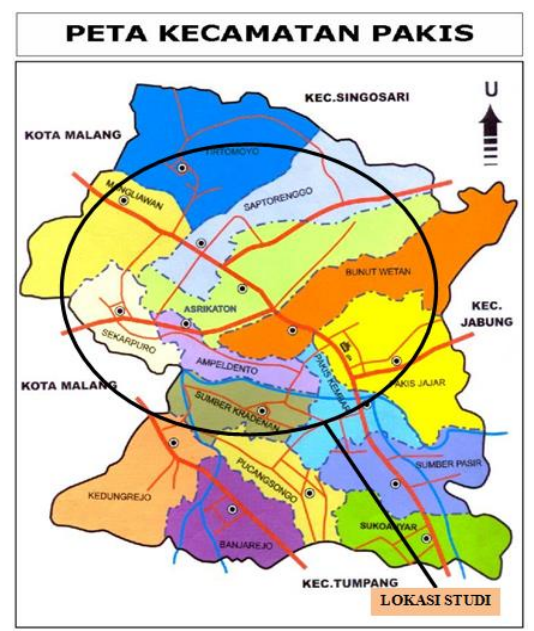

Gambar 2 Peta Lokasi Studi D.I. Pakis

Jenis metode penelitian dalam kajian ini adalah penelitian deskriptif yang merupakan peneliitian kasus dan penelitian lapangan. Penelitian ini bertujuan untuk menentukan nilai IPA yang efisien serta nilai FPR yang sesuai dengan jenis tanah (teoritis) sehingga dapat digunakan sebagai dasar dalam pemberian air irigasi di Daerah Irigasi Sonosari dan Pakis guna penghematan air irigasi.

Untuk memperlancar langkah - langkah perhitungan dalam studi ini, maka diperlukan tahapan - tahapan sebagai berikut :

1. Analisa ketersediaan air irigasi.

2. Pola tata tanam kondisi eksisting.

3. Menghitung kebutuhan air irigasi kondisi eksisting.

4. Evaluasi nilai FPR kondisi eksisting.

5. Analisa karakteristik pemberian air dan pembagian air irigasi.

6. Simulasi indeks penggunaan air (IPA).

7. Perhitungan neraca air. 
8. Menentukan Indeks Penggunaan Air (IPA).

9. Menghematan pemberian air irigasi.

\section{Kebutuhan Air Irigasi Metode FPR}

Untuk memudahkan pelaksanaan di lapangan, cara perhitungan kebutuhan tanaman di Jawa Timur memakai metode Faktor Palawija Relatif (FPR). Metode ini merupakan perbaikan dari metode-metode yang telah diterapkan di Negara Belanda, yaitu Metode Pasten. Berikut ini adalah persamaan untuk metode FPR (anonim, 2010) yaitu:

$$
\mathrm{FPR}=\frac{\mathrm{Q}}{\mathrm{LPR}}
$$

dimana :

$\mathrm{FPR}=$ faktor palawija relatif (lt/dt/ha.pol)

$\mathrm{Q}=$ debit air yang mengalir di sungai $(1 \mathrm{t} / \mathrm{dt})$

LPR = luas palawija relatif (ha.pol)

Kategori nilai FPR ditentukan di lapangan, tergantung pada kondisi tanah daerah penelitian. Jika nilai FPR kurang dari nilai FPR yang ditentukan maka perlu dilakukan pergiliran pemberian air. Adapun nilai-nilai FPR berdasarkan jenis tanah diperlihatkan pada Tabel 1.

Tabel 1. Nilai FPR Berdasarkan Jenis Tanah

\begin{tabular}{|c|c|c|c|}
\hline \multirow{2}{*}{ Jenis } & \multicolumn{3}{|c|}{ FPR (lt/dt/ha.pl) } \\
\cline { 2 - 4 } & $\begin{array}{c}\text { Air } \\
\text { Kurang }\end{array}$ & $\begin{array}{c}\text { Air } \\
\text { Cukup }\end{array}$ & $\begin{array}{c}\text { Air } \\
\text { Memadai/lebih }\end{array}$ \\
\hline Aluvial & 0,18 & $0,18-0,36$ & 0,36 \\
\hline Latosol & 0,12 & $0,12-0,23$ & 0,23 \\
\hline Grumosol & 0,06 & $0,06-0,12$ & 0,12 \\
\hline Giliran & Perlu & Mungkin & Tidak \\
\hline
\end{tabular}

Sumber: Dirjen Pengairan, (1997:1)

Luas Palawija Relatif merupakan hasil kali luas tanaman suatu jenis tanaman dikalikan dengan suatu nilai perbandingan antara kebutuhan air tanaman tersebut terhadap kebutuhan air oleh palawija. Pada dasarnya nilai LPR adalah perbandingan kebutuhan air antara jenis tanaman satu dengan jenis tanaman lain. Tanaman perbandingan yang digunakan adalah palawija yang memiliki nilai 1 (satu) (Dirjen Pengairan, 1997).

$$
\text { LPR }=\text { Luas Tanam } \mathrm{x} \text { Faktor }
$$

dimana :

$$
\text { LPR } \quad \begin{gathered}
\text { luas palawija relatif } \\
\text { (ha.pol) }
\end{gathered}
$$

Luas Tanam = luas lahan yang ditanami

(ha)

$\mathrm{K}=$ faktor konversi (pol)

Tabel 2. Nilai K untuk Berbagai Jenis Tanaman

\begin{tabular}{|l|c|}
\hline \multicolumn{1}{|c|}{ Jenis Tanaman } & $\begin{array}{c}\text { Faktor } \\
\text { Konversi }\end{array}$ \\
\hline Polowijo & 1,0 \\
\hline 1. yang perlu banyak air & 0,5 \\
\hline 2. yang perlu sedikit air & \\
\hline $\begin{array}{l}\text { Padi Rendeng/ Padi } \\
\text { Gadu Ijin }\end{array}$ & 20,0 \\
\hline 1. Bibit & 6,0 \\
\hline 2. Garap & 4,0 \\
\hline 3. Tanam & 1,5 \\
\hline Tebu & 0,0 \\
\hline 1. Tebu muda \\
\hline 2. Tebu tua
\end{tabular}

Sumber: Dirjen Pengairan, (1997:1)

\section{Sistem Giliran}

Sistem Giliran adalah cara pemberian air disaluran tersier atau saluran utama dengan interval waktu tertentu bila debit yang tersedia kurang dari faktor $\mathrm{K}$. Faktor $\mathrm{K}$ adalah perbandingan antara debit tersedia di bendung dengan debit yang dibutuhkan pada periode pembagian dan pemberian air. Jika persediaan air cukup maka faktor $\mathrm{K}>1$, sedangkan pada persediaan air kurang maka faktor $\mathrm{K}<1$. Rumus untuk menghitung faktor $\mathrm{K}$ (Departemen Pekerjaan Umum, 2005):

$$
\mathrm{K}=\frac{\text { Debit yang tersedia }}{\text { Debit yang dibutuhkan }}
$$

Pada kondisi air cukup (faktor $\mathrm{K}>1$ ), pembagian dan pemberian air adalah sama dengan rencana pembagian dan pemberian air. Pada saat terjadi kekurangan air $(\mathrm{K}<1)$, pembagian dan pemberian air disesuaikan dengan nilai faktor $\mathrm{K}$ yang sudah dihitung. Sistem giliran dapat dilakukan pada tingkat kwarter, tersier dan sekunder. Sejumlah petak (kwarter, tersier) dapat digabungkan menjadi satu blok giliran atau satu golongan. 
Tabel 3. Kriteria Pemberian Air dengan Faktor $\mathrm{K}$

\begin{tabular}{|l|l|}
\hline $\begin{array}{l}\text { Faktor } \mathrm{K}=0,75- \\
1,00\end{array}$ & Terus menerus \\
\hline $\begin{array}{l}\text { Faktor } \mathrm{K}=0,50- \\
0,75\end{array}$ & $\begin{array}{l}\text { Giliran di saluran } \\
\text { tersier }\end{array}$ \\
\hline $\begin{array}{l}\text { Faktor } \mathrm{K}=0,25- \\
0,50\end{array}$ & $\begin{array}{l}\text { Giliran di saluran } \\
\text { sekunder }\end{array}$ \\
\hline Faktor $\mathrm{K}<0,25$ & $\begin{array}{l}\text { Giliran di saluran } \\
\text { primer }\end{array}$ \\
\hline
\end{tabular}

Sumber: Departemen Pekerjaan Umum (2005:10)

Indeks Penggunaan Air

Perhitungan Indeks Penggunaan Air yaitu (Anonim, 2009, SK Dirjen Dirjen RLPS): Perbandingan antara kebutuhan air dengan ketersediaan air yang ada.

IPA $=\frac{\text { Kebutuhan Air Irigasi }}{\text { Ketersedian Air di Sungai }}$

Tabel 4. Klasifikasi Nilai Indeks Penggunaan Air (IPA)

\begin{tabular}{|l|l|l|l|}
\hline No. & Nilai IPA & Kelas & Skor \\
\hline 1 & $\leq 0,5$ & Baik & 1 \\
\hline 2 & $0,6-1,0$ & Sedang & 3 \\
\hline 3 & $\geq 1,0$ & Jelek & 5 \\
\hline
\end{tabular}

Sumber: Anonim, SK dirjen RLPS (2009)

\section{HASIL DAN PEMBAHASAN}

\section{Kebutuhan Air Irigasi Eksisting}

Berdasarkan data debit di D.I. Sonosari dan D.I. Pakis untuk kebutuhan air irigasi kondisi eksisting selama setahun maka perlu dilakukan rekap data per musim tanam untuk 12 petak tersier di D.I. Sonosari dan 10 petak tersier di D.I. Pakis. Dari hasil rekap data maka akan dipilih data debit kebutuhan air irigasi yang paling maksimum guna mengetahui nilai FPR yang paling maksimum sehingga didapatkan bahwa untuk nilai FPR di D.I. Sonosari masih tidak sesuai dengan nilai yang tercantum pada Tabel 1 yang dimana untuk D.I. Sonosari memiliki jenis tanah latosol dengan nilai untuk air cukup range dari 0,12 - 0,23. Sementara pada Daerah Irigasi Pakis, didapatkan bahwa untuk nilai FPR hampir sesuai dengan nilai yang tercantum pada tabel nilai FPR berdasarkan jenis tanah atau mendekati ketentuan range nilai FPR berdasarkan jenis tanah alluvial untuk kondisi air cukup dengan range dari $0,18-0,36$.
Tabel 5. Rekapitulasi Kebutuhan Air Irigasi Kondisi Eksisting Berdasarkan Debit Maksimum di Daerah Irigasi Sonosari

\begin{tabular}{|c|c|c|c|c|}
\hline Petak & $\begin{array}{l}\text { Periode } \\
\text { Tanam }\end{array}$ & $\begin{array}{c}\text { Debit } \\
\text { Maksimum }\end{array}$ & LPR & FPR \\
\hline \multirow{3}{*}{$\begin{array}{c}\text { Tersier } \\
\text { SS } 1\end{array}$} & $\mathrm{MH}$ & 62 & 239,5 & 0,26 \\
\hline & MK I & 56 & 184 & 0,3 \\
\hline & MK II & 36 & 114,5 & 0,31 \\
\hline \multirow{3}{*}{$\begin{array}{c}\text { Tersier } \\
\text { SS } 2\end{array}$} & $\mathrm{MH}$ & 208 & 922 & 0,23 \\
\hline & MK I & 184 & 600 & 0,31 \\
\hline & MK II & 82 & 263 & 0,31 \\
\hline \multirow{3}{*}{$\begin{array}{c}\text { Tersier } \\
\text { SS } 3\end{array}$} & $\mathrm{MH}$ & 46 & 180,5 & 0,25 \\
\hline & MK I & 48 & 148 & 0,32 \\
\hline & MK II & 26 & 78,5 & 0,33 \\
\hline \multirow{3}{*}{$\begin{array}{c}\text { Tersier } \\
\text { SS } 4\end{array}$} & $\mathrm{MH}$ & 281 & 1406 & 0,2 \\
\hline & MK I & 288 & 982,5 & 0,29 \\
\hline & MK II & 174 & 563 & 0,31 \\
\hline \multirow{3}{*}{$\begin{array}{c}\text { Tersier } \\
\text { SS } 5\end{array}$} & $\mathrm{MH}$ & 57 & 226 & 0,25 \\
\hline & MK I & 52 & 170 & 0,31 \\
\hline & MK II & 26 & 81 & 0,32 \\
\hline \multirow{3}{*}{$\begin{array}{c}\text { Tersier } \\
\text { SS } 6\end{array}$} & $\mathrm{MH}$ & 30 & 119 & 0,25 \\
\hline & MK I & 26 & 86 & 0,3 \\
\hline & MK II & 14 & 43 & 0,33 \\
\hline \multirow{3}{*}{$\begin{array}{c}\text { Tersier } \\
\text { SS } 7\end{array}$} & $\mathrm{MH}$ & 53 & 217 & 0,24 \\
\hline & MK I & 54 & 176 & 0,31 \\
\hline & MK II & 21 & 66,5 & 0,32 \\
\hline \multirow{3}{*}{$\begin{array}{c}\text { Tersier } \\
\text { SS } 8\end{array}$} & $\mathrm{MH}$ & 55 & 223 & 0,25 \\
\hline & MK I & 56 & 185 & 0,3 \\
\hline & MK II & 22 & 71,5 & 0,31 \\
\hline \multirow{3}{*}{$\begin{array}{c}\text { Tersier } \\
\text { SS } 9\end{array}$} & $\mathrm{MH}$ & 58 & 230,5 & 0,25 \\
\hline & MK I & 59 & 190 & 0,31 \\
\hline & MK II & 27 & 85,5 & 0,32 \\
\hline \multirow{3}{*}{$\begin{array}{c}\text { Tersier } \\
\text { SS } 10\end{array}$} & $\mathrm{MH}$ & 57 & 239,5 & 0,24 \\
\hline & MK I & 59 & 191 & 0,31 \\
\hline & MK II & 26 & 82,5 & 0,32 \\
\hline \multirow{3}{*}{$\begin{array}{c}\text { Tersier } \\
\text { SS } 11\end{array}$} & $\mathrm{MH}$ & 33 & 134 & 0,25 \\
\hline & MK I & 30 & 94 & 0,32 \\
\hline & MK II & 22 & 67 & 0,33 \\
\hline \multirow{3}{*}{$\begin{array}{c}\text { Tersier } \\
\text { SS } 12\end{array}$} & $\mathrm{MH}$ & 31 & 122 & 0,25 \\
\hline & MK I & 29 & 92 & 0,32 \\
\hline & MK II & 23 & 72 & 0,32 \\
\hline \multirow{3}{*}{ Intake } & $\overline{\mathrm{MH}}$ & 971 & 4259 & 0,23 \\
\hline & MK I & 941 & 3098,5 & 0,3 \\
\hline & MK II & 499 & 1588 & 0,31 \\
\hline
\end{tabular}

Sumber: Hasil Perhitungan, 2016 
Tabel 6. Rekapitulasi Kebutuhan Air Irigasi Kondisi Eksisting Berdasarkan Debit Maksimum di Daerah Irigasi Pakis

\begin{tabular}{|c|c|c|c|c|}
\hline Petak & $\begin{array}{c}\text { Period } \\
\text { e } \\
\text { Tanam }\end{array}$ & $\begin{array}{c}\text { Debit } \\
\text { Maksimu } \\
\text { m }\end{array}$ & $\begin{array}{c}\text { LPR } \\
\text { Maksimu } \\
\text { m }\end{array}$ & FPR \\
\hline \multirow{3}{*}{$\begin{array}{l}\text { T. SP } \\
1 \mathrm{~A} \mathrm{Ki}\end{array}$} & MH & 8 & 20 & 0,4 \\
\hline & MK I & 8 & 21 & 0,38 \\
\hline & MK II & 2 & 4 & 0,5 \\
\hline \multirow{3}{*}{$\begin{array}{c}\text { T. SP } 1 \\
\mathrm{Ki}\end{array}$} & $\mathrm{MH}$ & 54 & 155 & 0,35 \\
\hline & MK I & 71 & 180,5 & 0,39 \\
\hline & MK II & 46 & 118,5 & 0,39 \\
\hline \multirow{3}{*}{$\begin{array}{c}\text { T. SP } 1 \\
\text { Ka }\end{array}$} & $\mathrm{MH}$ & 203 & 538,5 & 0,38 \\
\hline & MK I & 260 & 674,5 & 0,39 \\
\hline & MK II & 203 & 514,5 & 0,39 \\
\hline \multirow{3}{*}{$\begin{array}{l}\text { T. SS } \\
1 \mathrm{~A} \mathrm{Ki}\end{array}$} & $\mathrm{MH}$ & 127 & 265,5 & 0,48 \\
\hline & MK I & 127 & 345,5 & 0,37 \\
\hline & MK II & 127 & 345,5 & 0,37 \\
\hline \multirow{3}{*}{$\begin{array}{c}\text { T. SS } 2 \\
\mathrm{Ki}\end{array}$} & $\mathrm{MH}$ & 106 & 293 & 0,36 \\
\hline & MK I & 99 & 249 & 0,4 \\
\hline & MK II & 92 & 145 & 0,63 \\
\hline \multirow{3}{*}{$\begin{array}{c}\text { T. SS } 3 \\
\mathrm{Ka}\end{array}$} & MH & 216 & 471,5 & 0,46 \\
\hline & MK I & 233 & 574,5 & 0,41 \\
\hline & MK II & 177 & 439,5 & 0,4 \\
\hline \multirow{3}{*}{$\begin{array}{c}\text { T. SS } 4 \\
\text { Ki }\end{array}$} & MH & 121 & 387 & 0,31 \\
\hline & MK I & 106 & 387 & 0,27 \\
\hline & MK II & 106 & 188 & 0,56 \\
\hline \multirow{3}{*}{$\begin{array}{c}\text { T. SS } 5 \\
\text { Ka }\end{array}$} & $\mathrm{MH}$ & 60 & 161 & 0,37 \\
\hline & MK I & 45 & 120 & 0,38 \\
\hline & MK II & 40 & 104 & 0,38 \\
\hline \multirow{3}{*}{$\begin{array}{c}\text { T. SS } 5 \\
\text { Te }\end{array}$} & $\mathrm{MH}$ & 16 & 40 & 0,4 \\
\hline & MK I & 19 & 50 & 0,38 \\
\hline & MK II & 16 & 40 & 0,4 \\
\hline \multirow{3}{*}{$\begin{array}{c}\text { T. SS } 5 \\
\mathrm{Ki}\end{array}$} & $\mathrm{MH}$ & 170 & 447 & 0,38 \\
\hline & MK I & 233 & 503 & 0,46 \\
\hline & MK II & 107 & 267 & 0,4 \\
\hline
\end{tabular}

Sumber: Hasil Perhitungan, 2016

Evaluasi Nilai FPR berdasarkan Kebutuhan Air Irigasi Kondisi Eksisting

Dari hasil evaluasi nilai FPR didapatkan 33 kali nilai FPR yang lebih dari 0,23 dan tidak sesuai dari total 36 kali dari total tiga kali musim tanam untuk 12 petak tersier selama setahun, jadi prosentase pemberian air berdasarkan nilai FPR adalah sebesar $94,44 \%$ di D.I. Sonosari. Sementera pada D.I. Pakis, berdasarkan evaluasi nilai FPR didapatkan bahwa nilai FPR hitung yang tidak sesuai dengan nilai FPR berdasarkan jenis tanah sebanyak 27 kali dari total tiga kali musim tanam untuk sepuluh petak tersier selama setahun, maka apabila diprosentasekan didapat nilai sebesar $90 \%$. Artinya kondisi antara kebutuhan dan ketersediaan air baik di D.I. Sonosari maupun
D.I. Pakis terjadi kelebihan air sehingga dinyatakan adanya pemborosan. Oleh sebab itu, perlu adanya upaya untuk mengurangi pemborosan tersebut dan salah satu caranya adalah mensimulasi nilai indeks penggunaan air (IPA) guna mendapatkan kebutuhan air irigasi dengan nilai FPR yang sesuai dengan ketentuan range yang ada.

Tabel 7. Evaluasi Nilai FPR D.I. Sonosari

\begin{tabular}{|c|c|c|c|c|}
\hline Petak & $\begin{array}{l}\text { Periode } \\
\text { Tanam }\end{array}$ & $\begin{array}{c}\text { FPR } \\
\text { hitung }\end{array}$ & $\begin{array}{l}\text { FPR } \\
\text { tabel }\end{array}$ & Keterangan \\
\hline \multirow{3}{*}{$\begin{array}{c}\text { Tersier } \\
\text { SS } 1\end{array}$} & $\mathrm{MH}$ & 0,259 & 0,23 & Tidak Sesuai \\
\hline & MK I & 0,304 & 0,23 & Tidak Sesuai \\
\hline & MK II & 0,314 & 0,23 & Tidak Sesuai \\
\hline \multirow{3}{*}{$\begin{array}{c}\text { Tersier } \\
\text { SS } 2\end{array}$} & MH & 0,226 & 0,23 & Sesuai \\
\hline & MK I & 0,307 & 0,23 & Tidak Sesuai \\
\hline & MK II & 0,312 & 0,23 & Tidak Sesuai \\
\hline \multirow{3}{*}{$\begin{array}{c}\text { Tersier } \\
\text { SS } 3\end{array}$} & MH & 0,255 & 0,23 & Tidak Sesuai \\
\hline & MK I & 0,324 & 0,23 & Tidak Sesuai \\
\hline & MK II & 0,331 & 0,23 & Tidak Sesuai \\
\hline \multirow{3}{*}{$\begin{array}{c}\text { Tersier } \\
\text { SS } 4\end{array}$} & MH & 0,2 & 0,23 & Sesuai \\
\hline & MK I & 0,293 & 0,23 & Tidak Sesuai \\
\hline & MK II & 0,309 & 0,23 & Tidak Sesuai \\
\hline \multirow{3}{*}{$\begin{array}{c}\text { Tersier } \\
\text { SS } 5\end{array}$} & MH & 0,252 & 0,23 & Tidak Sesuai \\
\hline & MK I & 0,306 & 0,23 & Tidak Sesuai \\
\hline & MK II & 0,321 & 0,23 & Tidak Sesuai \\
\hline \multirow{3}{*}{$\begin{array}{c}\text { Tersier } \\
\text { SS } 6\end{array}$} & $\mathrm{MH}$ & 0,252 & 0,23 & Tidak Sesuai \\
\hline & MK I & 0,302 & 0,23 & Tidak Sesuai \\
\hline & MK II & 0,326 & 0,23 & Tidak Sesuai \\
\hline \multirow{3}{*}{$\begin{array}{c}\text { Tersier } \\
\text { SS } 7\end{array}$} & $\mathrm{MH}$ & 0,244 & 0,23 & Tidak Sesuai \\
\hline & MK I & 0,307 & 0,23 & Tidak Sesuai \\
\hline & MK II & 0,316 & 0,23 & Tidak Sesuai \\
\hline \multirow{3}{*}{$\begin{array}{c}\text { Tersier } \\
\text { SS } 8\end{array}$} & MH & 0,247 & 0,23 & Tidak Sesuai \\
\hline & MK I & 0,303 & 0,23 & Tidak Sesuai \\
\hline & MK II & 0,308 & 0,23 & Tidak Sesuai \\
\hline \multirow{3}{*}{$\begin{array}{c}\text { Tersier } \\
\text { SS } 9\end{array}$} & $\mathrm{MH}$ & 0,252 & 0,23 & Tidak Sesuai \\
\hline & MK I & 0,311 & 0,23 & Tidak Sesuai \\
\hline & MK II & 0,316 & 0,23 & Tidak Sesuai \\
\hline \multirow{3}{*}{$\begin{array}{c}\text { Tersier } \\
\text { SS } 10\end{array}$} & MH & 0,238 & 0,23 & Tidak Sesuai \\
\hline & MK I & 0,309 & 0,23 & Tidak Sesuai \\
\hline & MK II & 0,315 & 0,23 & Tidak Sesuai \\
\hline \multirow{3}{*}{$\begin{array}{c}\text { Tersier } \\
\text { SS } 11\end{array}$} & $\mathrm{MH}$ & 0,246 & 0,23 & Tidak Sesuai \\
\hline & MK I & 0,319 & 0,23 & Tidak Sesuai \\
\hline & MK II & 0,328 & 0,23 & Tidak Sesuai \\
\hline \multirow{3}{*}{$\begin{array}{l}\text { Tersier } \\
\text { SS } 12\end{array}$} & $\mathrm{MH}$ & 0,254 & 0,23 & Tidak Sesuai \\
\hline & MK I & 0,315 & 0,23 & Tidak Sesuai \\
\hline & MK II & 0,319 & 0,23 & Tidak Sesuai \\
\hline \multirow{3}{*}{ Intake } & MH & 0,228 & 0,23 & Sesuai \\
\hline & MK I & 0,304 & 0,23 & Tidak Sesuai \\
\hline & MK II & 0,314 & 0,23 & Tidak Sesuai \\
\hline
\end{tabular}

Sumber: Hasil Perhitungan, 2016 
Tabel 8. Evaluasi Nilai FPR di D.I. Pakis

\begin{tabular}{|c|c|c|c|c|}
\hline Petak & $\begin{array}{c}\text { Periode } \\
\text { Tanam }\end{array}$ & $\begin{array}{c}\text { FPR } \\
\text { hitung }\end{array}$ & $\begin{array}{l}\text { FPR } \\
\text { tabel }\end{array}$ & Keterangan \\
\hline \multirow{3}{*}{$\begin{array}{l}\text { T. SP } \\
1 \mathrm{~A} \mathrm{Ki}\end{array}$} & MH & 0.40 & 0.36 & Tidak Sesuai \\
\hline & MK I & 0.38 & 0.36 & Tidak Sesuai \\
\hline & MK II & 0.50 & 0.36 & Tidak Sesuai \\
\hline \multirow{3}{*}{$\begin{array}{c}\text { T. SP } 1 \\
\text { Ki }\end{array}$} & $\mathrm{MH}$ & 0.35 & 0.36 & Sesuai \\
\hline & MK I & 0.39 & 0.36 & Tidak Sesuai \\
\hline & MK II & 0.39 & 0.36 & Tidak Sesuai \\
\hline \multirow{3}{*}{$\begin{array}{c}\text { T. SP } 1 \\
\text { Ka }\end{array}$} & $\mathrm{MH}$ & 0.38 & 0.36 & Tidak Sesuai \\
\hline & MK I & 0.39 & 0.36 & Tidak Sesuai \\
\hline & MK II & 0.39 & 0.36 & Tidak Sesuai \\
\hline \multirow{3}{*}{$\begin{array}{l}\text { T. SS } \\
1 \mathrm{~A} \mathrm{Ki}\end{array}$} & $\mathrm{MH}$ & 0.48 & 0.36 & Tidak Sesuai \\
\hline & MK I & 0.37 & 0.36 & Tidak Sesuai \\
\hline & MK II & 0.37 & 0.36 & Tidak Sesuai \\
\hline \multirow{3}{*}{$\begin{array}{c}\text { T. SS } 2 \\
\mathrm{Ki}\end{array}$} & $\mathrm{MH}$ & 0.36 & 0.36 & Tidak Sesuai \\
\hline & MK I & 0.40 & 0.36 & Tidak Sesuai \\
\hline & MK II & 0.63 & 0.36 & Tidak Sesuai \\
\hline \multirow{3}{*}{$\begin{array}{c}\text { T. SS } 3 \\
\mathrm{Ka}\end{array}$} & $\mathrm{MH}$ & 0.46 & 0.36 & Tidak Sesuai \\
\hline & MK I & 0.41 & 0.36 & Tidak Sesuai \\
\hline & MK II & 0.40 & 0.36 & Tidak Sesuai \\
\hline \multirow{3}{*}{$\begin{array}{c}\text { T. SS } 4 \\
\mathrm{Ki}\end{array}$} & $\mathrm{MH}$ & 0.31 & 0.36 & Sesuai \\
\hline & MK I & 0.27 & 0.36 & Sesuai \\
\hline & MK II & 0.56 & 0.36 & Tidak Sesuai \\
\hline \multirow{3}{*}{$\begin{array}{c}\text { T. SS } 5 \\
\text { Ka }\end{array}$} & $\mathrm{MH}$ & 0.37 & 0.36 & Tidak Sesuai \\
\hline & MK I & 0.38 & 0.36 & Tidak Sesuai \\
\hline & MK II & 0.38 & 0.36 & Tidak Sesuai \\
\hline \multirow{3}{*}{$\begin{array}{c}\text { T. SS } 5 \\
\text { Te }\end{array}$} & $\mathrm{MH}$ & 0.40 & 0.36 & Tidak Sesuai \\
\hline & MK I & 0.38 & 0.36 & Tidak Sesuai \\
\hline & MK II & 0.40 & 0.36 & Tidak Sesuai \\
\hline \multirow{3}{*}{$\begin{array}{c}\text { T. SS } 5 \\
\mathrm{Ki}\end{array}$} & $\mathrm{MH}$ & 0.38 & 0.36 & Tidak Sesuai \\
\hline & MK I & 0.46 & 0.36 & Tidak Sesuai \\
\hline & MK II & 0.40 & 0.36 & Tidak Sesuai \\
\hline
\end{tabular}

Sumber: Hasil Perhitungan, 2016

\section{Simulasi Indeks Penggunaan Air (IPA)}

Berdasarkan analisa kebutuhan air, nilai FPR dan karakteristik pemberian air irigasi diatas, maka perlu adanya upaya untuk menentukan nilai indeks penggunaan air (IPA) yang tepat guna penghematan air irigasi. Salah satu cara atau metode yang dapatkan digunakan adalah dengan cara mensimulasi nilai IPA yaitu mencoba-coba nilai IPA mulai dari 0,9 (kategori sedang) hingga batas yang telah ditentukan atau memenuhi syarat yaitu:

1. Nilai IPA di Intake sebagai kontrol tidak boleh melebihi 0,9 .

2. Nilai FPR tidak boleh melebihi ketentuan atau sesuai dengan Tabel 2.2 nilai FPR berdasarkan jenis tanah.

3. Nilai Faktor K harus melebihi 0,75.
4. Dalam studi ini, dilakukan simulasi IPA sebanyak lima kali percobaan dengan mencoba nilai IPA $0,9,0,8$, dan 0,7 yang dimana simulasi IPA dilakukan pada tiap musim tanam, yaitu musim hujan, musim kemarau I, dan musim kemarau II. Simulasi dilakukan berulang kali untuk menemukan nilai debit penghematan yang paling optimal dengan mengacu pada evaluasi nilai FPR pada tiap petak tersier. Selengkapnya tabel beserta grafik hasil simulasi IPA dengan nilai 0,7 per musim tanam berikut:

Tabel 9. Simulasi IPA = 0,7 (MH)

\begin{tabular}{|c|c|c|c|c|c|}
\hline \multirow[b]{2}{*}{ Petak } & \multirow{2}{*}{\begin{tabular}{|c|} 
Luas \\
Baku \\
Sawah \\
(ha)
\end{tabular}} & \multicolumn{2}{|c|}{ Coba-coba IPA } & \multirow[b]{2}{*}{$\begin{array}{c}\text { Ketersediaa } \\
\text { n Air Irigasi } \\
\text { (lt/dtk) }\end{array}$} & \multirow[b]{2}{*}{$\begin{array}{c}\text { Kebutuhan } \\
\text { Air Irigasi } \\
\text { (lt/dtk) }\end{array}$} \\
\hline & & IPA & $\begin{array}{c}\text { Kriteria } \\
\text { IPA }\end{array}$ & & \\
\hline [1] & [2] & [3] & [4] & [5] & [6] \\
\hline T. SS 1 & 45 & 0,700 & edang & 62,0 & 43,400 \\
\hline T. SS 2 & 192 & 0,700 & edano & 208 & 145,600 \\
\hline T. SS 3 & 33 & 0 & & & \\
\hline T. SS 4 & 287 & 700 & $\mathrm{~g}$ & 0 & 19 \\
\hline T. SS 5 & 36 & 0,700 & $\mathrm{~g}$ & 0 & \\
\hline T. SS 6 & 19 & 0,700 & Sedang & 00 & 21,000 \\
\hline T. SS 7 & 36 & 0,700 & Sedang & 53,000 & 37,100 \\
\hline T. SS 8 & 34 & 0,700 & S & & \\
\hline T. SS 9 & 36 & 0,700 & Sedang & 00 & 00 \\
\hline T. SS 10 & 42 & 0,700 & Sedang & 57,000 & 39,900 \\
\hline T. SS 11 & 23 & 0,700 & Sedang & 33,000 & 23,100 \\
\hline T. SS 12 & 18 & 0,700 & Sedang & 31,000 & 21,700 \\
\hline Sonosari & 801 & 0,817 & Sedang & 1060,000 & 865,611 \\
\hline
\end{tabular}

Sumber: Hasil Perhitungan, 2016

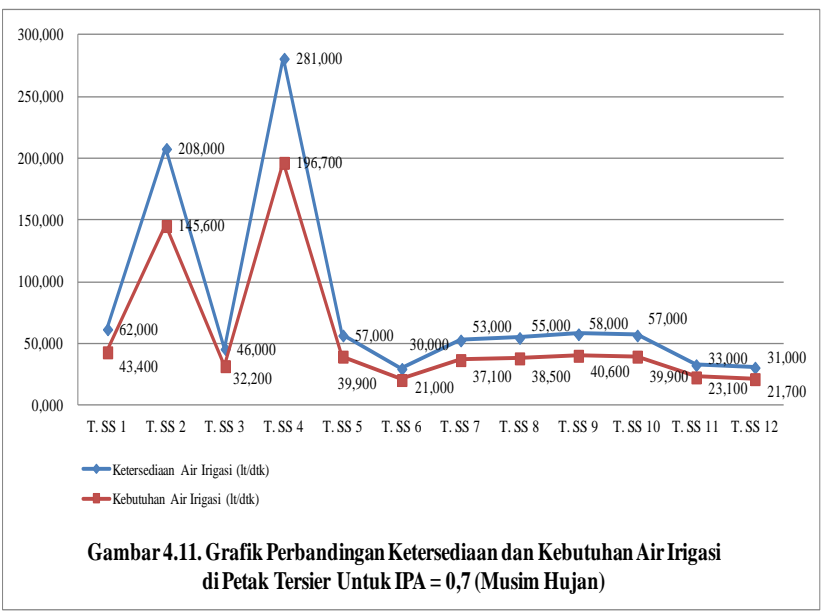

Gambar 3. Grafik Hubungan Perbandingan Ketersediaan dan Kebutuhan Air Irigasi di Petak Tersier untuk IPA $=0,7$ (Musim Hujan) 
Tabel 10. Simulasi IPA = 0,7 (MK I)

\begin{tabular}{|c|c|c|c|c|c|}
\hline \multirow[b]{2}{*}{ Petak } & \multirow{2}{*}{$\begin{array}{c}\text { Luas } \\
\text { Baku } \\
\text { Sawah } \\
\text { (ha) }\end{array}$} & \multicolumn{2}{|c|}{$\begin{array}{c}\text { Coba-coba } \\
\text { IPA }\end{array}$} & \multirow{2}{*}{$\begin{array}{c}\text { Ketersediaa } \\
\text { n Air Irigasi } \\
\text { (lt/dtk) }\end{array}$} & \multirow{2}{*}{$\begin{array}{c}\text { Kebutuhan } \\
\text { Air Irigasi } \\
\text { (lt/dtk) }\end{array}$} \\
\hline & & IPA & $\begin{array}{c}\text { Kriteri } \\
\mathbf{a} \\
\text { IPA }\end{array}$ & & \\
\hline [1] & [2] & [3] & [4] & [5] & [6] \\
\hline T. SS 1 & 45 & 0,700 & Sedang & 56,000 & 39,200 \\
\hline T. SS 2 & 192 & 0,700 & Sedang & 184,000 & 128,800 \\
\hline T. SS 3 & 33 & 0,700 & Sedang & 48,000 & 33,600 \\
\hline T. SS 4 & 287 & 0,700 & Sedang & 288,000 & 201,600 \\
\hline T. SS 5 & 36 & 0,700 & Sedang & 52,000 & 36,400 \\
\hline T. SS 6 & 19 & 0,700 & Sedang & 26,000 & 18,200 \\
\hline T. SS 7 & 36 & 0,700 & Sedang & 54,000 & 37,800 \\
\hline T. SS 8 & 34 & 0,700 & Sedang & 56,000 & 39,200 \\
\hline T. SS 9 & 36 & 0,700 & Sedang & 58,691 & 41,084 \\
\hline T. SS 10 & 42 & 0,700 & Sedang & 59,000 & 41,300 \\
\hline T. SS 11 & 23 & 0,700 & Sedang & 30,000 & 21,000 \\
\hline T. SS 12 & 18 & 0,700 & Sedang & 29,000 & 20,300 \\
\hline Sonosari & 801 & 0,798 & Sedang & 1058,000 & 844,044 \\
\hline
\end{tabular}

Sumber: Hasil Perhitungan, 2016

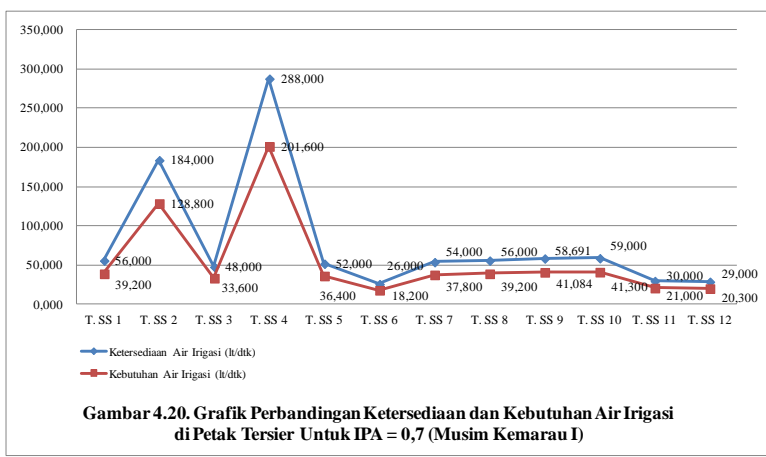

Gambar 4. Grafik Hubungan Perbandingan Ketersediaan dan Kebutuhan Air Irigasi di Petak Tersier untuk IPA $=0,7$ (Musim Kemarau I

Tabel 11. Simulasi IPA = 0,7 (MK II)

\begin{tabular}{|c|c|c|c|c|c|}
\hline \multirow[b]{2}{*}{ Petak } & \multirow{2}{*}{$\begin{array}{c}\text { Luas } \\
\text { Baku } \\
\text { Sawah } \\
\text { (ha) }\end{array}$} & \multicolumn{2}{|c|}{$\begin{array}{c}\text { Coba-coba } \\
\text { IPA }\end{array}$} & \multirow{2}{*}{$\begin{array}{c}\text { Ketersediaa } \\
\text { n Air Irigasi } \\
\text { (lt/dtk) }\end{array}$} & \multirow{2}{*}{$\begin{array}{c}\text { Kebutuha } \\
\text { n Air } \\
\text { Irigasi } \\
\text { (lt/dtk) }\end{array}$} \\
\hline & & IPA & $\begin{array}{c}\text { Kriteri } \\
\mathbf{a} \\
\text { IPA }\end{array}$ & & \\
\hline [1] & [2] & [3] & {$[4]$} & [D] & {$[0$} \\
\hline SS 1 & 45 & 0,700 & Sedan & & \\
\hline T. SS 2 & 192 & 0 & $\mathrm{~S}_{\mathrm{S}}$ & & \\
\hline T. SS 3 & 33 & 0 & Sedang & & \\
\hline T. SS 4 & 287 & 0,700 & Sedang & & \\
\hline SS 5 & 36 & J & Sedang & & \\
\hline 86 & 19 & 0 & $\mathrm{Sec}$ & & \\
\hline T. SS 7 & 36 & 0,700 & Sedang & & 700 \\
\hline T. SS 8 & 34 & 0,700 & Sedang & & 15,400 \\
\hline T. SS 9 & 36 & 0,700 & Sedang & & 18,900 \\
\hline SS 10 & $\overline{42}$ & 0,700 & \begin{tabular}{|l|} 
Sedang \\
\end{tabular} & & \\
\hline T. SS 11 & 23 & 0,700 & Sedang & & 00 \\
\hline T. SS 12 & 18 & 0,700 & Sedang & 23,000 & 16,100 \\
\hline onosari & 801 & 0,794 & Sedang & 565,000 & 448,394 \\
\hline
\end{tabular}

Sumber: Hasil Perhitungan, 2016

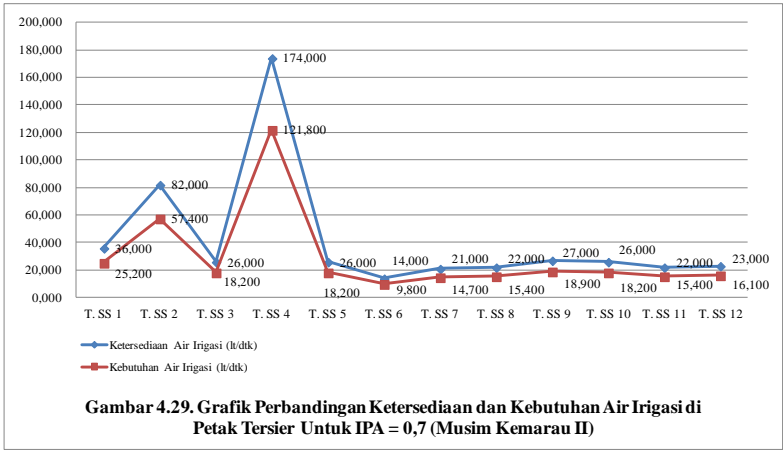

Gambar 5. Grafik Hubungan Perbandingan Ketersediaan dan Kebutuhan Air Irigasi di Petak Tersier untuk IPA $=0,55$ (Musim Kemarau II)

Sementara pada D.I. Pakis dilakukan simulasi IPA sebanyak lima kali percobaan dengan mencoba nilai IPA $0,9,0,8,0,7,0,6$, dan 0,55 yang dimana kelima simulasi IPA dilakukan pada tiap musim tanam, yaitu musim hujan, musim kemarau I, dan musim kemarau II. Simulasi dilakukan berulang kali untuk menemukan nilai debit penghematan yang paling optimal dengan mengacu pada evaluasi nilai FPR pada tiap petak tersier. Selengkapnya tabel beserta grafik hasil simulasi IPA dengan nilai 0,55 per musim tanam berikut:

Tabel 12 Simulasi IPA $=0,55(\mathrm{MH})$

\begin{tabular}{|c|c|c|c|c|c|c|}
\hline \multirow[b]{2}{*}{ Petak } & \multirow{2}{*}{$\begin{array}{l}\text { Luas Baku } \\
\text { Sawah (ha) }\end{array}$} & \multicolumn{2}{|c|}{ Evaluasi IPA } & \multirow{2}{*}{$\begin{array}{c}\text { Ketersediaan } \\
\text { Air Irigasi } \\
\text { (lt/dtk) }\end{array}$} & \multirow{2}{*}{$\begin{array}{c}\text { Kebutuhan } \\
\text { Air Irigasi } \\
\text { (lt/dtk) }\end{array}$} & \multirow{2}{*}{\begin{tabular}{|c|} 
FPR \\
$\left(\begin{array}{c}\text { It/dtk/ha.p } \\
\text { ol) }\end{array}\right.$ \\
\end{tabular}} \\
\hline & & IPA & Kriteria IPA & & & \\
\hline [1] & [2] & [3] & [4] & [5] & [6] & [7] \\
\hline D.I. Pakis & 726 & 0,55 & Sedang & 1084,00 & 594,55 & 0,21 \\
\hline T. SP 1A Ki & 5 & 0,55 & Sedang & 8,00 & 4,40 & 0,22 \\
\hline T. SP $1 \mathrm{Ki}$ & 40 & 0,55 & Sedang & 54,00 & 29,70 & 0,19 \\
\hline T. SP $1 \mathrm{Ka}$ & 158 & 0,55 & Sedang & 203,00 & 111,65 & 0,21 \\
\hline T. SS 1A Ki & 72 & 0,55 & Sedang & 127,00 & 69,85 & 0,26 \\
\hline T. SS $2 \mathrm{Ki}$ & 83 & 0,55 & Sedang & 106,00 & 58,30 & 0,20 \\
\hline T. SS $3 \mathrm{Ka}$ & 132 & 0,55 & Sedang & 216,00 & 118,80 & 0,25 \\
\hline T. SS $4 \mathrm{Ki}$ & 82 & 0,55 & Sedang & 121,00 & 66,55 & 0,17 \\
\hline T. SS $5 \mathrm{Ka}$ & 30 & 0,55 & Sedang & 60,00 & 33,00 & 0,20 \\
\hline T. SS $5 \mathrm{Te}$ & 10 & 0,55 & Sedang & 16,00 & 8,80 & 0,22 \\
\hline T. SS $5 \mathrm{Ki}$ & 114 & 0,55 & Sedang & 170,00 & 93,50 & 0,21 \\
\hline
\end{tabular}

Sumber: Hasil Perhitungan, 2016

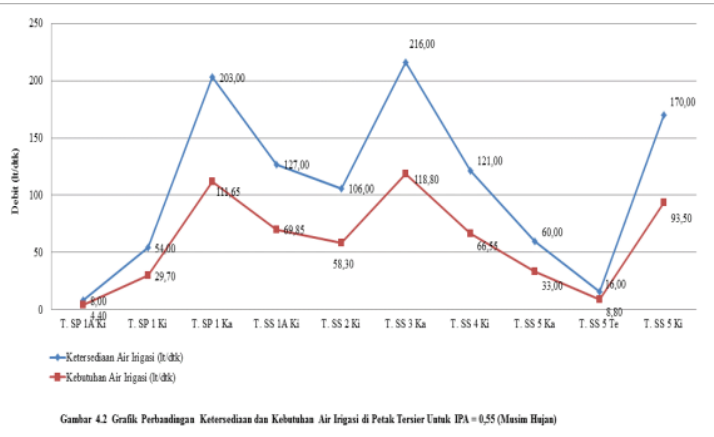

Gambar 6 Grafik Hubungan Perbandingan Ketersediaan dan Kebutuhan Air Irigasi di Petak Tersier untuk IPA = 0,55 (Musim Hujan) 
Tabel 13 Simulasi IPA = 0,55 (MK I)

\begin{tabular}{|c|c|c|c|c|c|c|}
\hline \multirow[b]{2}{*}{ Petak } & \multirow{2}{*}{$\begin{array}{l}\text { Luas Baku } \\
\text { Sawah (ha) }\end{array}$} & \multicolumn{2}{|c|}{ Evaluasi IPA } & \multirow{2}{*}{$\begin{array}{c}\text { Ketersediaan } \\
\text { Air Irigasi } \\
\text { (lt/dtk) }\end{array}$} & \multirow{2}{*}{$\begin{array}{c}\text { Kebutuhan } \\
\text { Air Irigasi } \\
\text { (lt/dtk) }\end{array}$} & \multirow{2}{*}{$\begin{array}{c}\text { FPR } \\
\text { (lt/dtk/ha.p } \\
\text { ol) }\end{array}$} \\
\hline & & IPA & Kriteria IPA & & & \\
\hline$[1]$ & [2] & {$[3]$} & [4] & {$[5]$} & [6] & [7] \\
\hline D.I. Pakis & 726 & 0,55 & Sedang & 1205,00 & 660,55 & 0,21 \\
\hline T. SP 1A Ki & 5 & 0,55 & Sedang & 8,00 & 4,40 & 0,21 \\
\hline T. SP $1 \mathrm{Ki}$ & 40 & 0,55 & Sedang & 71,00 & 39,05 & 0,22 \\
\hline T. SP $1 \mathrm{Ka}$ & 158 & 0,55 & Sedang & 260,00 & 143,00 & 0,21 \\
\hline \begin{tabular}{|l} 
T. SS 1A Ki \\
\end{tabular} & 72 & 0,55 & Sedang & 127,00 & 69,85 & 0,20 \\
\hline T. SS $2 \mathrm{Ki}$ & 83 & 0,55 & Sedang & 99,00 & 54,45 & 0,22 \\
\hline T. SS $3 \mathrm{Ka}$ & 132 & 0,55 & Sedang & 233,00 & 128,15 & 0,22 \\
\hline T. SS 4 Ki & 82 & 0,55 & Sedang & 106,00 & 58,30 & 0,15 \\
\hline \begin{tabular}{|l} 
T. SS $5 \mathrm{Ka}$ \\
\end{tabular} & 30 & 0,55 & Sedang & 45,00 & 24,75 & 0,21 \\
\hline T. SS $5 \mathrm{Te}$ & 10 & 0,55 & Sedang & 19,00 & 10,45 & 0,21 \\
\hline T. SS $5 \mathrm{Ki}$ & 114 & 0,55 & Sedang & 233,00 & 128,15 & 0,25 \\
\hline
\end{tabular}

Sumber: Hasil Perhitungan, 2016

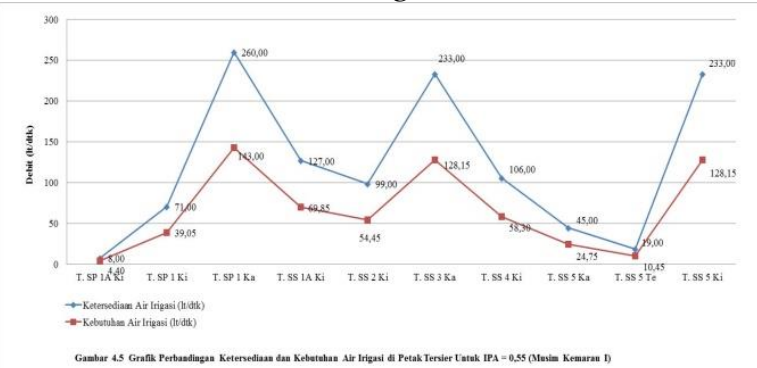

Gambar 7 Grafik Hubungan Perbandingan Ketersediaan dan Kebutuhan Air Irigasi di Petak Tersier untuk IPA $=0,55($ Musim Kemarau I)

Tabel 14 Simulasi IPA = 0,55 (MK II)

\begin{tabular}{|c|c|c|c|c|c|c|}
\hline \multirow[b]{2}{*}{ Petak } & \multirow{2}{*}{$\begin{array}{l}\text { Luas Baku } \\
\text { Sawah (ha) }\end{array}$} & \multicolumn{2}{|c|}{ Evaluasi IPA } & \multirow{2}{*}{$\begin{array}{c}\text { Ketersediaan } \\
\text { Air Irigasi } \\
\text { (lt/dtk) }\end{array}$} & \multirow{2}{*}{$\begin{array}{c}\text { Kebutuhan } \\
\text { Air Irigasi } \\
\text { (lt/dtk) }\end{array}$} & \multirow{2}{*}{$\begin{array}{c}\text { FPR } \\
\text { (lt/dtk/ha.p } \\
\text { ol) }\end{array}$} \\
\hline & & IPA & Kriteria IPA & & & \\
\hline [1] & [2] & [3] & [4] & [5] & [6] & [7] \\
\hline D.I. Pakis & 726 & 0,55 & Sedang & 962,20 & 503,80 & 0,23 \\
\hline T. SP $1 \mathrm{~A} \mathrm{Ki}$ & 5 & 0,55 & Sedang & 2,00 & 1,10 & 0,28 \\
\hline T. SP $1 \mathrm{Ki}$ & 40 & 0,55 & Sedang & 46,00 & 25,30 & 0,21 \\
\hline T. SP $1 \mathrm{Ka}$ & 158 & 0,55 & Sedang & 203,00 & 111,65 & 0,22 \\
\hline T. SS 1A Ki & 72 & 0,55 & Sedang & 127,00 & 69,85 & 0,20 \\
\hline T. SS $2 \mathrm{Ki}$ & 83 & 0,55 & Sedang & 92,00 & 50,60 & 0,35 \\
\hline T. SS $3 \mathrm{Ka}$ & 132 & 0,55 & Sedang & 177,00 & 97,35 & 0,22 \\
\hline T. SS $4 \mathrm{Ki}$ & 82 & 0,55 & Sedang & 106,00 & 58,30 & 0,31 \\
\hline T. SS $5 \mathrm{Ka}$ & 30 & 0,55 & Sedang & 40,00 & 22,00 & 0,21 \\
\hline T. SS $5 \mathrm{Te}$ & 10 & 0,55 & Sedang & 16,00 & 8,80 & 0,22 \\
\hline T. SS $5 \mathrm{Ki}$ & 114 & 0,55 & Sedang & 107,00 & 58,85 & 0,22 \\
\hline
\end{tabular}

Sumber: Hasil Perhitungan, 2016

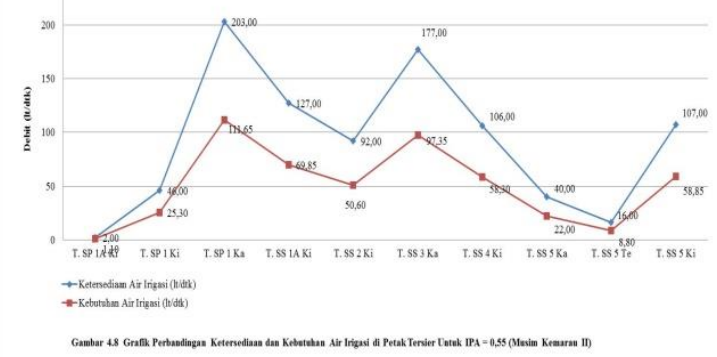

Gambar 8 Grafik Hubungan Perbandingan Ketersediaan dan Kebutuhan Air Irigasi di Petak Tersier untuk IPA $=0,55$ (Musim Kemarau II)

\section{Penghematan Air Irigasi}

Dari hasil simulasi IPA didapatkan bahwa dengan mencoba-coba nilai IPA $=0,7$ (kategori sedang) memiliki hasil terbesar yaitu 194,389 1t/dtk (Musim Hujan), 213,956 lt/dtk (Musim Kemarau I) dan 116,606 lt/dtk (Musim Kemarau II) pada intake. Untuk penghematan pemberian air irigasi dengan mencoba-coba nilai FPR didapatkan bahwa $\mathrm{FPR}=0,12$ memiliki hasil terbesar yaitu 363,009 1t/dtk (Musim Hujan), 500,620 lt/dtk (Musim Kemarau I) dan 275,346 lt/dtk (Musim Kemarau II) pada intake. Sementara untuk D.I. Pakis didapatkan bahwa untuk penghematan pemberian air irigasi yang paling besar, yaitu pada efisiensi 55\% di musim kemarau I sebesar $540,45 \mathrm{lt} / \mathrm{dtk}$ dengan nilai IPA $=0,55$ yang dimana apabila dilihat pada kriteria pemberian airnya termasuk kategori sedang. Sementara untuk penghematan pemberian air irigasi hasil simulasi indeks penggunaan air (IPA) pada Daerah Irigasi Pakis, pada musim hujan didapatkan debit sebesar 486,45 lt/dtk dan musim kemarau II sebesar 412,20 lt/dtk dengan nilai IPA $=0,55$ dan efisiensi sebesar $55 \%$.

Tabel 15 Penghematan Air Irigasi Musim Hujan (IPA = 0,7) D.I. Sonosari

\begin{tabular}{|c|c|c|c|c|}
\hline \multirow[b]{2}{*}{ Petak } & \multirow{2}{*}{\begin{tabular}{|c|} 
Luas \\
Baku \\
Sawah \\
\end{tabular}} & \multirow{2}{*}{$\begin{array}{c}\text { Kebutuhan } \\
\text { Air Irigasi } \\
\text { Eksisting }\end{array}$} & Kebutuhan & Penghematan \\
\hline & & & $\begin{array}{c}\text { IPA = 0,7 } \\
(\text { lt } / \mathbf{d t k})\end{array}$ & $\begin{array}{c}\text { IPA = 0,7 } \\
\text { (It/dtk) }\end{array}$ \\
\hline Tersier SS 1 & 45 & 62,000 & 43,400 & 18,600 \\
\hline Tersier SS 2 & 192 & 208,000 & 145,600 & 62,400 \\
\hline Tersier SS 3 & 33 & 46,000 & 32,200 & 13,800 \\
\hline Tersier SS 4 & 287 & 281,000 & 196,700 & 84,300 \\
\hline Tersier SS 5 & 36 & 57,000 & 39,900 & 17,100 \\
\hline Tersier SS 6 & 19 & 30,000 & 21,000 & 9,000 \\
\hline Tersier SS 7 & 36 & 53,000 & 37,100 & 15,900 \\
\hline Tersier SS 8 & 34 & 55,000 & 38,500 & 16,500 \\
\hline Tersier SS 9 & 36 & 58,000 & 40,600 & 17,400 \\
\hline Tersier SS 10 & 42 & 57,000 & 39,900 & 17,100 \\
\hline Tersier SS 11 & 23 & 33,000 & 23,100 & 9,900 \\
\hline Tersier SS 12 & 18 & 31,000 & 21,700 & 9,300 \\
\hline D.I. Sonosari & 801 & 1060,000 & 865,611 & 194,389 \\
\hline
\end{tabular}

sumber: Hasil Perhitungan, 2016

Tabel 16 Penghematan Air Irigasi Musim Kemarau I (IPA = 0,7) D.I. Sonosari

\begin{tabular}{|c|c|c|c|c|}
\hline \multirow[b]{2}{*}{ Petak } & \multirow{2}{*}{\begin{tabular}{|c|} 
Luas \\
Baku \\
Sawah \\
\end{tabular}} & \multirow{2}{*}{$\begin{array}{c}\text { Kebutuhan } \\
\text { Air Irigasi } \\
\text { Eksisting } \\
\end{array}$} & \multirow{2}{*}{\begin{tabular}{c|} 
Kebutuhan \\
IPA = 0,7 \\
(lt/dtk) \\
\end{tabular}} & \multirow{2}{*}{$\begin{array}{c}\text { Penghematan } \\
\text { IPA = 0,7 } \\
\text { (lt/dtk) }\end{array}$} \\
\hline & & & & \\
\hline Tersier SS 1 & 45 & 56,000 & 39,200 & 16,800 \\
\hline Tersier SS 2 & 192 & 184,000 & 128,800 & 55,200 \\
\hline Tersier SS 3 & 33 & 48,000 & 33,600 & 14,400 \\
\hline Tersier SS 4 & 287 & 288,000 & 201,600 & 86,400 \\
\hline Tersier SS 5 & 36 & 52,000 & 36,400 & 15,600 \\
\hline Tersier SS 6 & 19 & 26,000 & 18,200 & 7,800 \\
\hline Tersier SS 7 & 36 & 54,000 & 37,800 & 16,200 \\
\hline Tersier SS 8 & 34 & 56,000 & 39,200 & 16,800 \\
\hline Tersier SS 9 & 36 & 58,691 & 41,084 & 17,607 \\
\hline Tersier SS 10 & 42 & 59,000 & 41,300 & 17,700 \\
\hline Tersier SS 11 & 23 & 30,000 & 21,000 & 9,000 \\
\hline Tersier SS 12 & 18 & 29,000 & 20,300 & 8,700 \\
\hline D.I. Sonosari & 801 & 1058,000 & 844,044 & 213,956 \\
\hline
\end{tabular}

sumber: Hasil Perhitungan, 2016 
Tabel 17 Penghematan Air Irigasi Musim Kemarau II (IPA = 0,7) D.I. Sonosari

\begin{tabular}{|c|c|c|c|c|}
\hline \multirow{2}{*}{ Petak } & \multirow{2}{*}{$\begin{array}{c}\text { Baku } \\
\text { Bawah }\end{array}$} & $\begin{array}{c}\text { Kebutuhan } \\
\text { Air Irigasi } \\
\text { Eksisting }\end{array}$ & $\begin{array}{c}\text { Kebutuhan } \\
\text { IPA = 0,7 } \\
\text { (It/dtk) }\end{array}$ & $\begin{array}{c}\text { IPA = 0,7 } \\
\text { (lt/dtk) }\end{array}$ \\
\hline Tersier SS 1 & 45 & 36,000 & 25,200 & 10,800 \\
\hline Tersier SS 2 & 192 & 82,000 & 57,400 & 24,600 \\
\hline Tersier SS 3 & 33 & 26,000 & 18,200 & 7,800 \\
\hline Tersier SS 4 & 287 & 174,000 & 121,800 & 52,200 \\
\hline Tersier SS 5 & 36 & 26,000 & 18,200 & 7,800 \\
\hline Tersier SS 6 & 19 & 14,000 & 9,800 & 4,200 \\
\hline Tersier SS 7 & 36 & 21,000 & 14,700 & 6,300 \\
\hline Tersier SS 8 & 34 & 22,000 & 15,400 & 6,600 \\
\hline Tersier SS 9 & 36 & 27,000 & 18,900 & 8,100 \\
\hline Tersier SS 10 & 42 & 26,000 & 18,200 & 7,800 \\
\hline Tersier SS 11 & 23 & 22,000 & 15,400 & 6,600 \\
\hline Tersier SS 12 & 18 & 23,000 & 16,100 & 6,900 \\
\hline D.I. Sonosari & 801 & 565,000 & 448,394 & 116,606 \\
\hline
\end{tabular}
sumber: Hasil Perhitungan, 2016

Tabel 18 Penghematan Air Irigasi Musim Kemarau II (IPA $=0,7)$ D.I. Sonosari

\begin{tabular}{|c|c|c|c|c|}
\hline \multirow[b]{2}{*}{ Petak } & \multirow{2}{*}{$\begin{array}{c}\text { Luas } \\
\text { Baku } \\
\text { Sawah } \\
\end{array}$} & \multirow{2}{*}{$\begin{array}{c}\text { Kebutuhan } \\
\text { Air Irigasi } \\
\text { Eksisting }\end{array}$} & Kebutuhan & Penghematan \\
\hline & & & $\begin{array}{c}\text { FPR }=0,12 \\
\text { (lt/dtk) }\end{array}$ & $\begin{array}{c}\text { FPR }=0,12 \\
\text { (lt/dtk) }\end{array}$ \\
\hline Tersier SS 1 & 45 & 62,000 & 28,740 & 33,260 \\
\hline Tersier SS 2 & 192 & 208,000 & 110,640 & 97,360 \\
\hline Tersier SS 3 & 33 & 46,000 & 21,660 & 24,340 \\
\hline Tersier SS 4 & 287 & 281,000 & 168,720 & 112,280 \\
\hline Tersier SS 5 & 36 & 57,000 & 27,120 & 29,880 \\
\hline Tersier SS 6 & 19 & 30,000 & 14,280 & 15,720 \\
\hline Tersier SS 7 & 36 & 53,000 & 26,040 & 26,960 \\
\hline Tersier SS 8 & 34 & 55,000 & 26,760 & 28,240 \\
\hline Tersier SS 9 & 36 & 58,000 & 27,660 & 30,340 \\
\hline Tersier SS 10 & 42 & 57,000 & 28,740 & 28,260 \\
\hline Tersier SS 11 & 23 & 33,000 & 16,080 & 16,920 \\
\hline Tersier SS 12 & 18 & 31,000 & 14,640 & 16,360 \\
\hline D.I. Sonosari & 801 & 1060,000 & 696,991 & 363,009 \\
\hline
\end{tabular}

Sumber: Hasil Perhitungan, 2016

Tabel 19 Penghematan Air Irigasi Musim Kemarau II (IPA $=0,7)$ D.I. Sonosari

\begin{tabular}{|c|c|c|c|c|}
\hline \multirow[b]{2}{*}{ Petak } & \multirow{2}{*}{$\begin{array}{c}\text { Luas } \\
\text { Baku } \\
\text { Sawah }\end{array}$} & \multirow{2}{*}{$\begin{array}{c}\text { Kebutuhan } \\
\text { Air Irigasi } \\
\text { Eksisting }\end{array}$} & \multirow{2}{*}{$\begin{array}{c}\text { Kebutuhan } \\
\text { FPR }=0,12 \\
(\mathbf{l t} / \mathbf{d t k})\end{array}$} & \multirow{2}{*}{$\begin{array}{c}\text { Penghematan } \\
\text { FPR }=0,12 \\
(\mathbf{l t} / \mathbf{d t k})\end{array}$} \\
\hline & & & & \\
\hline Tersier SS 1 & 45 & 56,000 & 22,080 & 33,920 \\
\hline Tersier SS 2 & 192 & 184,000 & 72,000 & 112,000 \\
\hline Tersier SS 3 & 33 & 48,000 & 17,760 & 30,240 \\
\hline Tersier SS 4 & 287 & 288,000 & 117,900 & 170,100 \\
\hline Tersier SS 5 & 36 & 52,000 & 20,400 & 31,600 \\
\hline Tersier SS 6 & 19 & 26,000 & 10,320 & 15,680 \\
\hline Tersier SS 7 & 36 & 54,000 & 21,120 & 32,880 \\
\hline Tersier SS 8 & 34 & 56,000 & 22,200 & 33,800 \\
\hline Tersier SS 9 & 36 & 58,691 & 22,800 & 35,891 \\
\hline Tersier SS 10 & 42 & 59,000 & 22,920 & 36,080 \\
\hline Tersier SS 11 & 23 & 30,000 & 11,280 & 18,720 \\
\hline Tersier SS 12 & 18 & 29,000 & 11,040 & 17,960 \\
\hline D.I. Sonosari & 801 & 1058,000 & 557,380 & 500,620 \\
\hline
\end{tabular}

Sumber: Hasil Perhitungan, 2016
Tabel 20 Penghematan Air Irigasi Musim Kemarau II (IPA = 0,7) D.I. Sonosari

\begin{tabular}{|c|c|c|c|c|}
\hline \multirow{2}{*}{ Petak } & Luas & Kebutuhan & Kebutuhan & Penghematan \\
\cline { 4 - 5 } & Baku & Air Irigasi & FPR = 0,12 & FPR = 0,12 \\
Sawah & Eksisting & (lt/dtk) & (lt/dtk) \\
\hline Tersier SS 1 & 45 & 36,000 & 13,740 & 22,260 \\
\hline Tersier SS 2 & 192 & 82,000 & 31,560 & 50,440 \\
\hline Tersier SS 3 & 33 & 26,000 & 9,420 & 16,580 \\
\hline Tersier SS 4 & 287 & 174,000 & 67,560 & 106,440 \\
\hline Tersier SS 5 & 36 & 26,000 & 9,720 & 16,280 \\
\hline Tersier SS 6 & 19 & 14,000 & 5,160 & 8,840 \\
\hline Tersier SS 7 & 36 & 21,000 & 7,980 & 13,020 \\
\hline Tersier SS 8 & 34 & 22,000 & 8,580 & 13,420 \\
\hline Tersier SS 9 & 36 & 27,000 & 10,260 & 16,740 \\
\hline Tersier SS 10 & 42 & 26,000 & 9,900 & 16,100 \\
\hline Tersier SS 11 & 23 & 22,000 & 8,040 & 13,960 \\
\hline Tersier SS 12 & 18 & 23,000 & 8,640 & 14,360 \\
\hline D.I. Sonosari & 801 & 565,000 & 289,654 & 275,346 \\
\hline Surmber: H & &
\end{tabular}

Sumber: Hasil Perhitungan, 2016

Tabel 21 Penghematan Air Irigasi Musim Hujan (IPA $=0,55)$ D.I. Pakis

\begin{tabular}{|c|c|c|c|c|c|}
\hline & Luas & Kebutuhan & Kebutuhan & Efisiensi & Penghematan \\
\hline Petak & $\begin{array}{c}\text { Baku } \\
\text { Sawah } \\
\text { (ha) } \\
\end{array}$ & $\begin{array}{c}\text { Air Irigasi } \\
\text { Eksisting } \\
\text { (lt/dtk) } \\
\end{array}$ & $\begin{array}{c}\text { IPA 0,55 } \\
\text { (lt/dt) }\end{array}$ & $\begin{array}{c}\text { IPA } 0,55 \\
(\%)\end{array}$ & $\begin{array}{c}\text { IPA 0,55 } \\
\text { (lt/dt) }\end{array}$ \\
\hline T. SP $1 \mathrm{~A} \mathrm{Ki}$ & 5 & 8,00 & 4,40 & 55 & 3,60 \\
\hline T. SP $1 \mathrm{Ki}$ & 40 & 54,00 & 29,70 & 55 & 24,30 \\
\hline T. SP $1 \mathrm{Ka}$ & 158 & 203,00 & 111,65 & 55 & 91,35 \\
\hline T. SS $1 \mathrm{~A} \mathrm{Ki}$ & 72 & 127,00 & 69,85 & 55 & 57,15 \\
\hline T. SS $2 \mathrm{Ki}$ & 83 & 106,00 & 58,30 & 55 & 47,70 \\
\hline T. SS $3 \mathrm{Ka}$ & 132 & 216,00 & 118,80 & 55 & 97,20 \\
\hline T. SS $4 \mathrm{Ki}$ & 82 & 121,00 & 66,55 & 55 & 54,45 \\
\hline T. SS $5 \mathrm{Ka}$ & 30 & 60,00 & 33,00 & 55 & 27,00 \\
\hline T. SS $5 \mathrm{Te}$ & 10 & 16,00 & 8,80 & 55 & 7,20 \\
\hline T. SS $5 \mathrm{Ki}$ & 114 & 170,00 & 93,50 & 55 & 76,50 \\
\hline D.I. Pakis & 726 & 1081,00 & 594,55 & 55 & 486,45 \\
\hline
\end{tabular}

Sumber: Hasil Perhitungan, 2016

Tabel 22 Penghematan Air Irigasi Musim Kemarau I (IPA = 0,55) D.I. Pakis

\begin{tabular}{|c|c|c|c|c|c|}
\hline & Luas & Kebutuhan & Kebutuhan & Efisiensi & \begin{tabular}{|l|} 
Penghematan \\
\end{tabular} \\
\hline Petak & $\begin{array}{c}\text { Baku } \\
\text { Sawah } \\
\text { (ha) }\end{array}$ & $\begin{array}{c}\text { Air Irigasi } \\
\text { Eksisting } \\
\text { (lt/dtk) }\end{array}$ & $\begin{array}{c}\text { IPA 0,55 } \\
\text { (lt/dt) }\end{array}$ & $\begin{array}{c}\text { IPA 0,55 } \\
(\%)\end{array}$ & $\begin{array}{c}\text { IPA 0,55 } \\
\text { (lt/dt) }\end{array}$ \\
\hline T. SP 1A Ki & 5 & 8,00 & 4,40 & 55 & 3,60 \\
\hline T. SP $1 \mathrm{Ki}$ & 40 & 54,00 & 39,05 & 55 & 31,95 \\
\hline T. SP $1 \mathrm{Ka}$ & 158 & 203,00 & 143,00 & 55 & 117,00 \\
\hline T. SS $1 \mathrm{~A} \mathrm{Ki}$ & 72 & 127,00 & 69,85 & 55 & 57,15 \\
\hline T. SS $2 \mathrm{Ki}$ & 83 & 106,00 & 54,45 & 55 & 44,55 \\
\hline T. SS $3 \mathrm{Ka}$ & 132 & 216,00 & 128,15 & 55 & 104,85 \\
\hline T. SS $4 \mathrm{Ki}$ & 82 & 121,00 & 58,30 & 55 & 47,70 \\
\hline T. SS $5 \mathrm{Ka}$ & 30 & 60,00 & 24,75 & 55 & 20,25 \\
\hline T. SS $5 \mathrm{Te}$ & 10 & 16,00 & 10,45 & 55 & 8,55 \\
\hline T. SS $5 \mathrm{Ki}$ & 114 & 170,00 & 128,15 & 55 & 104,85 \\
\hline D.I. Pakis & 726 & 1081,00 & 660,55 & 55 & 540,45 \\
\hline
\end{tabular}

Sumber: Hasil Perhitungan, 2016 
Tabel 23 Penghematan Air Irigasi Musim Kemarau II (IPA = 0,55) D.I. Pakis

\begin{tabular}{|c|c|c|c|c|c|}
\hline & Luas & Kebutuhan & \begin{tabular}{|l|} 
Kebutuhan \\
\end{tabular} & Efisiensi & \begin{tabular}{|l|} 
Penghematan \\
\end{tabular} \\
\hline Petak & $\begin{array}{c}\text { Baku } \\
\text { Sawah } \\
\text { (ha) }\end{array}$ & $\begin{array}{c}\text { Air Irigasi } \\
\text { Eksisting } \\
\text { (lt/dtk) }\end{array}$ & $\begin{array}{c}\text { IPA 0,55 } \\
\text { (It/dt) }\end{array}$ & $\begin{array}{c}\text { IPA } 0,55 \\
(\%)\end{array}$ & $\begin{array}{c}\text { IPA 0,55 } \\
\text { (lt/dt) }\end{array}$ \\
\hline T. SP $1 \mathrm{~A} \mathrm{Ki}$ & 5 & 8,00 & 1,10 & 55 & 0,90 \\
\hline T. SP $1 \mathrm{Ki}$ & 40 & 54,00 & 25,30 & 55 & 20,70 \\
\hline T. SP $1 \mathrm{Ka}$ & 158 & 203,00 & 111,65 & 55 & 91,35 \\
\hline \begin{tabular}{|c|} 
T. SS $1 \mathrm{~A} \mathrm{Ki}$ \\
\end{tabular} & 72 & 127,00 & 69,85 & 55 & 57,15 \\
\hline T. SS $2 \mathrm{Ki}$ & 83 & 106,00 & 50,60 & 55 & 41,40 \\
\hline T. SS $3 \mathrm{Ka}$ & 132 & 216,00 & 97,35 & 55 & 79,65 \\
\hline T. SS $4 \mathrm{Ki}$ & 82 & 121,00 & 58,30 & 55 & 47,70 \\
\hline T. SS $5 \mathrm{Ka}$ & 30 & 60,00 & 22,00 & 55 & 18,00 \\
\hline T. SS $5 \mathrm{Te}$ & 10 & 16,00 & 8,80 & 55 & 7,20 \\
\hline T. SS $5 \mathrm{Ki}$ & 114 & 170,00 & 58,85 & 55 & 48,15 \\
\hline \begin{tabular}{|l|} 
D.I. Pakis \\
\end{tabular} & 726 & 1081,00 & 503,80 & 55 & 412,20 \\
\hline
\end{tabular}

Sumber: Hasil Perhitungan, 2016

\section{KESIMPULAN DAN SARAN Kesimpulan}

Dari hasil pembahasan studi ini maka dapat diambil beberapa kesimpulan diantaranya adalah:

1. Dari hasil evaluasi nilai FPR didapatkan 33 kali nilai FPR yang lebih dari 0,23 dan tidak sesuai dari total 36 kali dari total tiga kali musim tanam untuk 12 petak tersier selama setahun, jadi prosentase pemberian air berdasarkan nilai FPR adalah sebesar 94,44\% di D.I. Sonosari. Sementara pada D.I. Pakis berdasarkan perhitungan kebutuhan air irigasi eksisting dan dilakukan evaluasi nilai FPR dimana telah ditetapkan ketentuan untuk jenis tanah alluvial maka range nilai FPR yang dipakai, yaitu 0,18 - 0,36. Dari hasil evaluasi nilai FPR didapatkan 27 nilai FPR yang lebih besar dari 0,36 atau tidak sesuai dari total tiga kali musim tanam untuk sepuluh petak tersier, maka prosentase yang dihasilkan adalah $90 \%$. Nilai yang tidak sesuai dengan tabel nilai FPR berdasarkan jenis tanah dapat mempengaruhi kebutuhan air irigasi sehingga menyebabkan pemberian air tidak merata baik di D.I. Sonosari maupun D.I. Pakis.

2. Karakeristik berdasarkan hasil perhitungan dapat dilihat bahwa nilai IPA untuk Daerah Irigasi Sonoasari lebih atau sama dengan 1 sehingga menyebabkan kondisi jelek dikarenakan air yang diberikan pada petak tersier sama besarnya dengan jumlah air yang tersedia. Sedangkan untuk nilai $\mathrm{K}$ pada tiap petak tersier didapatkan nilai $=1$ atau lebih dari 0,75 sehingga pendistribusian air untuk daerah tersebut dilakukan secara terus menerus dikarenakan jumlah air yang tersedia cukup dengan jumlah air yang dibutuhkan pada tiap petak tersier. Sementara pada D.I. Pakis berdasarkan hasil perhitungan pemberian dan pembagian air kondisi pada D.I. Pakis karena tiap petak air yang diberikan pada tiap petak tersier sama besarnya dengan air yang tersedia sehingga didapatkan bahwa nilai IPA $=1$, sehingga menurut kriteria IPA, apabila nilai IPA > 0,9 maka pemberian dan pembagian air untuk tiap petak tersier termasuk kategori jelek. Sedangkan untuk nilai faktor $\mathrm{K}$ didapatkan nilai $=1$, maka menurut kriteria nilai faktor $\mathrm{K}$ pemberian air dilakukan secara terus menerus karena apabila nilai faktor $\mathrm{K}>0,75$ dilakukan pemberian air secara terus menerus karena ketersediaan air cukup untuk tiap petak tersier.

3. Berdasarkan hasil perhitungan penghematan pemberian air irigasi didapatkan bahwa dengan mencoba-coba nilai IPA $=0,7$ (kategori sedang) memiliki hasil terbesar yaitu 194,389 lt/dtk (Musim Hujan), 213,956 lt/dtk (Musim Kemarau I) dan 116,606 lt/dtk (Musim Kemarau II) pada intake. Sedangkan untuk penghematan pemberian air irigasi dengan mencoba-coba nilai FPR didapatkan bahwa FPR $=0,12$ memiliki hasil terbesar yaitu 363,009 1t/dtk (Musim Hujan), 500,620 1t/dtk (Musim Kemarau I) dan 275,346 1t/dtk (Musim Kemarau II) pada intake. Sementara pada D.I. Pakis didapatkan bahwa untuk penghematan pemberian air irigasi yang paling besar, yaitu pada efisiensi 55\% di musim kemarau I sebesar 540,45 1t/dtk dengan nilai IPA $=0,55$ yang termasuk kategori sedang. Sementara untuk penghematan pemberian air irigasi dengan nilai IPA dan efisiensi yang sama pada musim hujan didapatkan debit sebesar 486,45 lt/dtk dan musim kemarau II sebesar 412,20 lt/dtk.

\section{Saran}

Adapun saran yang dapat diberikan berdasarkan hasil perhitungan dan analisa dalam pengerjaan tugas akhir ini antara lain sebagai berikut

1. Untuk perhitungan kebutuhan air irigasi dengan menggunakan metode LPR-FPR 
hendaknya lebih memperhitungkan nilai FPR berdasarkan jenis tanah.

2. Untuk instansi terkait atau pengelola diharapkan dapat lebih rutin dalam hal pengecekan dan pemeliharaan daerah irigasi tersebut. Serta menyediakan data dan melakukan pengukuran secara berkala dan terjadwal khususnya dalam bidang kualitas air dan data waduk lainnya sebagai referensi bagi peneliti untuk melaksanakan penelitiannya dengan baik dan sesuai dengan perkembangan zaman yang menuntut penelitian lebih lanjut.

\section{DAFTAR PUSTAKA}

Anonim, 2009. SK Dirjen Rehabilitasi Lahan dan Perhutanan Sosial (RLPS), Perhitungan Indeks Pengunaan Air. Jakarta: Departemen Kehutanan.

Anonim. 2010. Kriteria Perencanaan Jaringan Irigasi KP-01, Kriteria Perencanaan Penunjan . Bandung: Ditjen. Pengairan Dep. PU Galang Persada.
Departemen Pekerjaan Umum. 2005. Penguatan Masyarakat Petani Pemakai Air Dalam Operasi Pemeliharaan Jaringan Irigasi (Pd T-08-2005-A). Jakarta: Departemen Pekerjaan Umum.

Direktorat Jenderal Rehabilitasi Lahan dan Perhutanan Sosial (RLPS). 2005. Pedoman Monitoring dan Evaluasi Pengelolaan DAS. Jakarta: Departemen Kehutanan.

Ditjen Pengairan. 1997. Pedoman Umum Operasi \& Pemeliharaan Jaringan Irigasi. Bandung: Direktorat Jenderal Pengairan, Dep. PU - Japan International Cooperation Agency (JICA).

Indriatno, M.N. 2013. Simulasi Penggunaan Lahan untuk Pengurangan Indeks Penggunaan Air di Sub DAS Cacaban, Kecamatan Karanggayam, Kabupaten Kebumen. 